University of Nebraska - Lincoln

DigitalCommons@University of Nebraska - Lincoln

Papers in the Earth and Atmospheric Sciences Earth and Atmospheric Sciences, Department

1994

\title{
Further Evidence of Lead Contamination of Omaha Skeletons
}

\author{
A. Mohamad Ghazi \\ Georgia State University, mghazi@gsu.edu \\ Karl J. Reinhard \\ University of Nebraska-Lincoln, kreinhard1@mac.com \\ Mary Anne Holmes \\ University of Nebraska-Lincoln, mholmes2@unl.edu \\ Eric M. Durrance \\ University of Nebraska-Lincoln
}

Follow this and additional works at: https://digitalcommons.unl.edu/geosciencefacpub

Part of the Anthropology Commons, and the Geochemistry Commons

Ghazi, A. Mohamad; Reinhard, Karl J.; Holmes, Mary Anne; and Durrance, Eric M., "Further Evidence of Lead Contamination of Omaha Skeletons" (1994). Papers in the Earth and Atmospheric Sciences. 70. https://digitalcommons.unl.edu/geosciencefacpub/70

This Article is brought to you for free and open access by the Earth and Atmospheric Sciences, Department of at DigitalCommons@University of Nebraska - Lincoln. It has been accepted for inclusion in Papers in the Earth and Atmospheric Sciences by an authorized administrator of DigitalCommons@University of Nebraska - Lincoln. 
Published in the American Journal of Physical Anthropology 95 (1994): 427-434.

Copyright 1994, Wiley-Liss. Used by permission.

\title{
Brief Communication: \\ Further Evidence of Lead Contamination of Omaha Skeletons
}

\author{
A. Mohamad Ghazi, Karl J. Reinhard, Mary Anne Holmes and Eric Durrance \\ Departments of Geology (A.M.G., M.A.H., E.D.) and Anthropology (K.J.R.), \\ University of Nebraska-Lincoln, Lincoln, Nebraska
}

Key words: Element lead, Pb, Contamination, Poisoning, Trace

Received February 18, 1993; accepted April 9, 1994.

\begin{abstract}
A previous analysis of Omaha skeletons dating between A.D. 1780 and 1820 revealed the presence of lead in all skeletons with high concentrations in children and adult males (Reinhard and Ghazi [1992] Am. J. Phys. Anthropol. 89: 183-195). Two likely explanations for the high lead levels were presented: 1) metabolic absorption of lead and 2) diagenetic uptake of lead by the bones from postmortem application of pigments to the corpse. Two types of lead were available to the Omaha tribe: 1) Mississippi Valley type, and 2) non-Mississippi Valley type. It has been suggested that red-lead pigment mixed with mercury sulfide (cinnabar) applied to the corpse may have been one of the sources of lead found in bones. Further isotopic analyses of samples of pigment and metallic lead artifacts associated with the skeletons revealed that non-Mississippi Valley type lead is present in the pigment while Mississippi Valley type lead comes from metallic artifacts. Both lead and mercury were found in the pigment samples, verifying that a lead-based pigment mixed with cinnabar-based pigment was used as a cosmetic by the Omaha. Isotopic analysis of lead in skeletons indicates that the pigment contributed most to lead content of bone. This new evidence clarifies the previous study and suggests specific mechanisms by which lead became incorporated into bone.
\end{abstract}

The results of previous analyses of lead concentrations in Omaha skeletons from Nebraska were difficult to interpret precisely: the lead could be of either metabolic or diagenetic origin and the immediate source of the lead was unclear (Reinhard and Ghazi, 1992). Interestingly, adult males had higher lead levels than adult females. We attributed this to increased premortem exposure of lead among males as opposed to females (Reinhard and Ghazi, 1992). Although it was believed that the high levels of lead implied lead ingestion and metabolic absorption in part, some postmortem application of lead-based pigment to corpses could have been a source of contamination. This latter mechanism was termed "culturally introduced diagenetic lead." Significantly, red pigment was found on most of the crania from the largest Omaha cemeteries, 25DK10. In addition, historical evidence exists of trade with the Omaha in yellow lead-based pigment, and that red lead-based pigment was mixed with vermillion (cinnabar) as a common cosmetic (Figure 1). Reinhard and Ghazi (1992: 191) stated that

Red lead-based pigment was also traded to Native Americans. In 1822, one trader working near Tongas, Alaska, specifically requests from his supplier 30-40 pounds of "red lead" to be mixed with "vermillion" (Morrison, 1920). Although this reference is far afield from Nebraska, it does indicate that red leadbased pigment was available in the early 1800 s and could be mixed with vermillion. If this also occurred in the Plains, the application of this pigment mixture could have introduced lead directly on the corpse. 


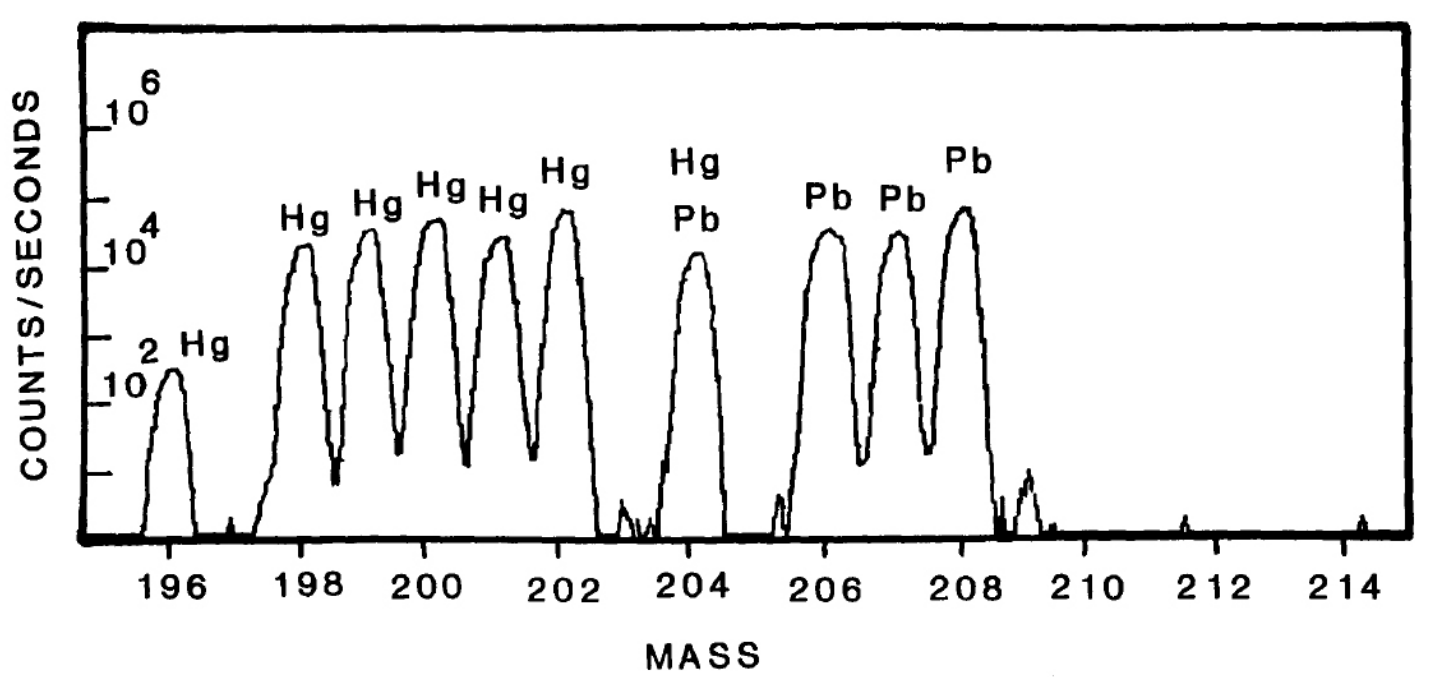

Fig. 1. Mass spectrum of a cosmetic pigment showing isotopes of mercury and lead. Data were collected in semi-scan mode using 40,080 channels in 65 seconds.

Red pigment was imported from fur traders for facial application, a practice which is noted for many upper Missouri River tribes in ethnohistoric records. The application of this pigment to the dead increases the possibility that culturally introduced diagenetic lead could have contributed to the lead values noted for the Omaha (Ghazi et al. 1992).

\section{SAMPLES AND ANALYTICAL RESULTS}

New analyses have been carried out on several Omaha pigments. Samples of pigments were analyzed by inductively coupled plasmamass spectrometry (ICP-MS). Two samples of pigment were removed directly from two crania from 25DK10. One sample came from an artifact not associated with the burials. While preparing Omaha artifacts for curation, Dr. Thomas Myers (Curator of Anthropology, Nebraska State Museum) discovered fine red powder leaking from a skin bag and provided the powder for analysis. The bag dates from the mid-1800s.

In order to discern which skeletons produced diagenetic signals, and which produced possible metabolic signals, another avenue of study focused on documenting the distribution of pigment application on the skeletons. This was done by examining each bone from each skeleton for evidence of red pigmentation. The skeletons were then classified as being heavily painted, lightly painted, or unpainted.

\section{RESULTS}

All three of the pigments analyzed by ICP-MS consisted of lead and mercury, demonstrating conclusively that mixing of lead-mercury based pigments did take place in historic times in $\mathrm{Ne}$ braska among the Omaha.

With adults, the pigment was applied to the face and sometimes the chest. Thus, contamination of rib samples with pigment in some individuals is a possibility since the pigment would settle on the ribs as the bodies decomposed. With infants, the pigment was applied to the face and scalp area. Because of the heavier application of lead to the heads of infants and the shorter distance between the cranium and the ribs in an infant burial, lead might more readily transport to the ribs of infants. Also, the more porous nature of infant bone would facilitate uptake of lead. Concerning the behavior of mercury, it should be noted that, whereas bone hydroxyapatite crystals have a high affinity for lead, they do not for mercury. Unless non-apatite components of bone bind mercury, mercury does not accumulate in bone. Since the processing of the bone for ICP-MS results in the destruction of the protein, mercury was not found in the bone samples.

The data regarding distribution of paint on adults and children are presented in Table 1a. 
TABLE 1a. Skeletal pigment distribution compared to Pb concentration ${ }^{1}$

\begin{tabular}{|c|c|c|}
\hline \multicolumn{3}{|l|}{ Infants and young children } \\
\hline $25 \mathrm{DK} 2 \mathrm{~b}$ s 26 & Cranium, clavicles, vertebrae, ribs $^{2}$ & 55.4 \\
\hline 25DK2b s11 & Cranium, rib $^{2}$ & 7.7 \\
\hline $25 \mathrm{DK} 10 \mathrm{i} 27 \mathrm{~b}$ & Ribs, humeri, radii, ulnae, femora, scapulae, clavicles ${ }^{2}$ & $2,567.0$ \\
\hline $25 \mathrm{DK} 10 \mathrm{i} 29 \mathrm{a}$ & Cranium, cervicals, clavicles, humerus, ulnae, os coxa ${ }^{2}$ & 13.2 \\
\hline $25 \mathrm{DK} 10 \mathrm{i} 51$ & ${\text { Cranium, } \text { clavicle }^{2}}^{2}$ & 887.6 \\
\hline $25 \mathrm{DK} 2 \mathrm{~b}$ s 26 & Mandible $^{3}$ & 49.9 \\
\hline $25 \mathrm{DK} 2 \mathrm{~b}$ s 34 & Rt. scapula ${ }^{3}$ & 32.8 \\
\hline $25 \mathrm{DK} 2 \mathrm{a}$ i1 & Sternum ${ }^{3}$ & 4.8 \\
\hline $25 \mathrm{DK} 10 \mathrm{i} 3$ & Cranium $^{3}$ & 134.4 \\
\hline $25 \mathrm{DK} 10$ i 8 & Cranium $^{3}$ & 256.5 \\
\hline 25DK10 i11 & Cranium $^{3}$ & 479.2 \\
\hline 25DK10 i14 & Cranium $^{3}$ & 222.6 \\
\hline 25DK10 i33a & Mandible $^{3}$ & 73.5 \\
\hline $25 \mathrm{DK} 10 \mathrm{i} 53$ & Cranium $^{3}$ & 74.5 \\
\hline $25 \mathrm{DK} 10$ i54 & Cranium $^{3}$ & 248.7 \\
\hline 25DK10 i56 & Cranium $^{3}$ & 196.1 \\
\hline 25DK2a s1 & None & 7.1 \\
\hline 25DK2a s18 & None & 29.5 \\
\hline 25DK2a i2 & None & 71.2 \\
\hline $25 \mathrm{DK} 10$ i 48 & None & 11.4 \\
\hline $25 \mathrm{DK} 10 \mathrm{i} 41$ & None & 9.7 \\
\hline 25DK10 i29 & None & 68.4 \\
\hline $25 \mathrm{DK} 10 \mathrm{i} 35$ & None & 9.1 \\
\hline $25 \mathrm{DK} 10 \mathrm{i} 29 \mathrm{a}$ & None & 13.2 \\
\hline $25 \mathrm{DK} 10 \mathrm{i} 23 \mathrm{a}$ & None & 228.3 \\
\hline $25 \mathrm{DK} 10 \mathrm{i} 23 \mathrm{~b}$ & None & 331.1 \\
\hline 25DK10 i55 & None & 44.4 \\
\hline $25 \mathrm{DK} 10 \mathrm{i} 33 \mathrm{~b}$ & Probably $^{3}$ (skeleton fragmentary) & 63.8 \\
\hline $25 \mathrm{DK} 2 \mathrm{a}$ i2 & Indeterminate (skeleton fragmentary) & 498.8 \\
\hline \multicolumn{3}{|l|}{ Adults } \\
\hline $25 \mathrm{DK} 10 \mathrm{i} 15$ & Face, clavicle, coracoid process scapula ${ }^{2}$ & 165.3 \\
\hline $25 \mathrm{DK} 10 \mathrm{i} 21$ & Face, clavicle, sternum ${ }^{2}$ & 210.5 \\
\hline $25 \mathrm{DK} 10$ i 28 & Face, clavicle, sternum, rib $^{2}$ & 271.1 \\
\hline 25DK10 i31 & Clavicles, ribs, sternum, humeri ${ }^{2}$ & 117.8 \\
\hline 25DK2b s27 & Clavicle $^{3}$ & 47.8 \\
\hline 25DK10 i13 & Frontal $^{3}$ & 33.4 \\
\hline $25 \mathrm{DK} 10 \mathrm{i} 44$ & Frontal, face ${ }^{3}$ & 19.6 \\
\hline $25 \mathrm{DK} 10 \mathrm{i} 38$ & None & 14.3 \\
\hline $25 \mathrm{DK} 10 \mathrm{i} 37$ & None & 13.7 \\
\hline 25DK2a s17 & None & 36.4 \\
\hline $25 \mathrm{DK} 2 \mathrm{a}$ s17 repeat run & & 48.8 \\
\hline $25 \mathrm{DK} 10 \mathrm{i} 4$ & Indeterminate (Skull is absent) & 185.9 \\
\hline \multicolumn{3}{|l|}{ Age unknown } \\
\hline $25 \mathrm{DK} 10 \mathrm{i} 10$ & None & 862.5 \\
\hline
\end{tabular}

The skeletons are identified in three categories: those that were heavily painted, those that were lightly painted (single deposits of pigment on one or two skeletal elements, usually the skull), and those that were not painted. The lead concentrations for each category vary widely. Thus, paint alone cannot account for the measured lead values. However, some interesting trends are evident in the means of the paint categories and are listed in Table lb. These values indicate that there is a tendency for painted burials to exhibit higher concentrations of lead. A Fishers LSD analysis indicates that although heavily and lightly painted categories are not significantly different from each other, the non-painted

\begin{tabular}{|c|c|c|}
\hline & Children & Adults \\
\hline Heavily painted & $706.2 \mu \mathrm{g} / \mathrm{g}$ & $191.2 \mu \mathrm{g} / \mathrm{g}$ \\
\hline Lightly painted & $162.45 \mu \mathrm{g} / \mathrm{g}$ & $33.6 \mu \mathrm{g} / \mathrm{g}$ \\
\hline Not painted & $74.9 \mu \mathrm{g} / \mathrm{g}$ & $21.5 \mu \mathrm{g} / \mathrm{g}$ \\
\hline \multirow[t]{2}{*}{ ANOVA } & $\mathrm{F}=3.35$ & $\mathrm{~F}=16.66^{\circ}$ \\
\hline & $P=0.0521$ & $P=0.0022$ \\
\hline
\end{tabular}

individuals are significantly different from both painted categories. Means and standard deviations for the categories are presented in Table 2.

The mean concentrations for adult males and adult females are $185.0 \mu \mathrm{g} / \mathrm{g}$ and $23.5 \mu \mathrm{g} / \mathrm{g}$, respectively. Previously, the difference between 
TABLE 2. Means and standard deviations for categories of painted and non-painted individuals ${ }^{1}$

\begin{tabular}{lrrr}
\hline Category & $\mathrm{n}$ & Mean & SD \\
\hline Heavily painted subadult & 5 & 706.2 & 988.6 \\
Lightly painted subadult & 11 & 161.2 & 132.2 \\
Unpainted subadult & 11 & 74.8 & 101.4 \\
Heavily painted adult & 4 & 191.2 & 56.6 \\
Lightly painted adult & 3 & 33.6 & 11.5 \\
Unpainted adult & 3 & 21.5 & 10.6 \\
\hline
\end{tabular}

${ }^{1}$ Units of measure are $\mu \mathrm{g} / \mathrm{g}$.

male and female values (Reinhard and Ghazi 1991, Figure 2) has been interpreted as a function of different premortem exposure to lead. This view must now be modified: it is probable that the higher lead values in adult males is due to heavier application of paint to the corpse. Thus, it appears that many of the lead values result from postmortem application of paint. The evidence clearly indicates that postmortem application of paint caused the introduction of lead into the bones. However, postmortem application does not apply to non-painted individuals, and cannot explain the high lead levels among them.

\section{PREMORTEM ABSORPTION}

The lead concentrations found in a small number of burials cannot be explained by postmortem contamination and diagenesis. These burials are neither painted nor contained lead artifacts (Table 3). The range of values from these burials is 7.1 to $331.1 \mu \mathrm{g} / \mathrm{g}$ of ashed bone. Reinhard and Ghazi (1992) have shown the mean lead concentrations in soil and animal bone to be $19.9 \mu \mathrm{g} / \mathrm{g}$ and $1.36 \mu \mathrm{g} / \mathrm{g}$, respectively. The low amount of lead in the soils and low uptake of lead exhibited by the animal bone is not consistent with the values of Omaha skeletons not associated with lead offerings or artifacts. All of the Omaha skeletal values exceed those of the animal bone, while the average for the Omaha skeletons of $69.3 \mu \mathrm{g} / \mathrm{g}$ of ashed bone is very much higher than that of animal bone. Considering that the data indicate minimal absorption of lead by animal bone from the soils, it is probable that the values from these burials reflect premortem ingestion and absorption in life.
To further evaluate whether or not metabolic absorption occurred, lead isotope ratios were determined. Lead isotope ratios are based on the relative amount of the isotopes of lead $\left({ }^{204} \mathrm{~Pb}\right.$, ${ }^{206} \mathrm{~Pb},{ }^{207} \mathrm{~Pb}$, and ${ }^{208} \mathrm{~Pb}$ ). Important for this analysis is the distinction between Mississippi River Valley type (MVT) lead deposits and non-Mississippi River Valley lead deposits. Lead from Mississippi Valley type deposits is highly enriched in the radiogenic isotopes in comparison to non-Mississippi type deposits. MVTs are carbonate rock-hosted lead-zinc deposits formed by hydrothermal activity at convergent tectonic plate margins. The isotope ratio specific to the lead in the pigment is typical of a non-Mississippi River Valley type (Table 4, Figure 2). The isotope ratios from metallic lead artifacts found with the burials is typical of Mississippi River Valley type lead mines (Table 5, Figure 2). The lead isotope ratios of six burials were studied. Most exhibited a signal consistent with non-Mississippi Valley type deposits, probably from pigments. Student t-tests (Table 6) show less significant difference between the isotope ratios of the pigments and skeletons than artifacts and skeletons. However, one of the skeletons (25DK10 i23b) exhibited a value intermediate between the two sources (Figure 2). It is probable that this intermediate value represents a mixture of the two types of lead. The metallic lead could only come from lead artifacts traded along the Missouri River. Since no lead artifacts were found with this burial, it is likely that the ratio reflects ingestion and absorption of metallic lead.

\section{CONCLUSIONS}

Most lead values found in Omaha skeletons can be explained as due to postmortem burial treatments which involved painting the corpses with a lead and mercury based pigment. The lead component of the pigment was transferred to the hydroxyapatite crystals of individual skeletons. The highest lead values reflect this postmortem treatment. There are, however, a series of values that cannot be explained in this way. Since diagenetic soil to bone transfer is minimal, these lower values may represent premortem ingestion and absorption of lead. The lead isotope ratio study of six individuals reveals that 

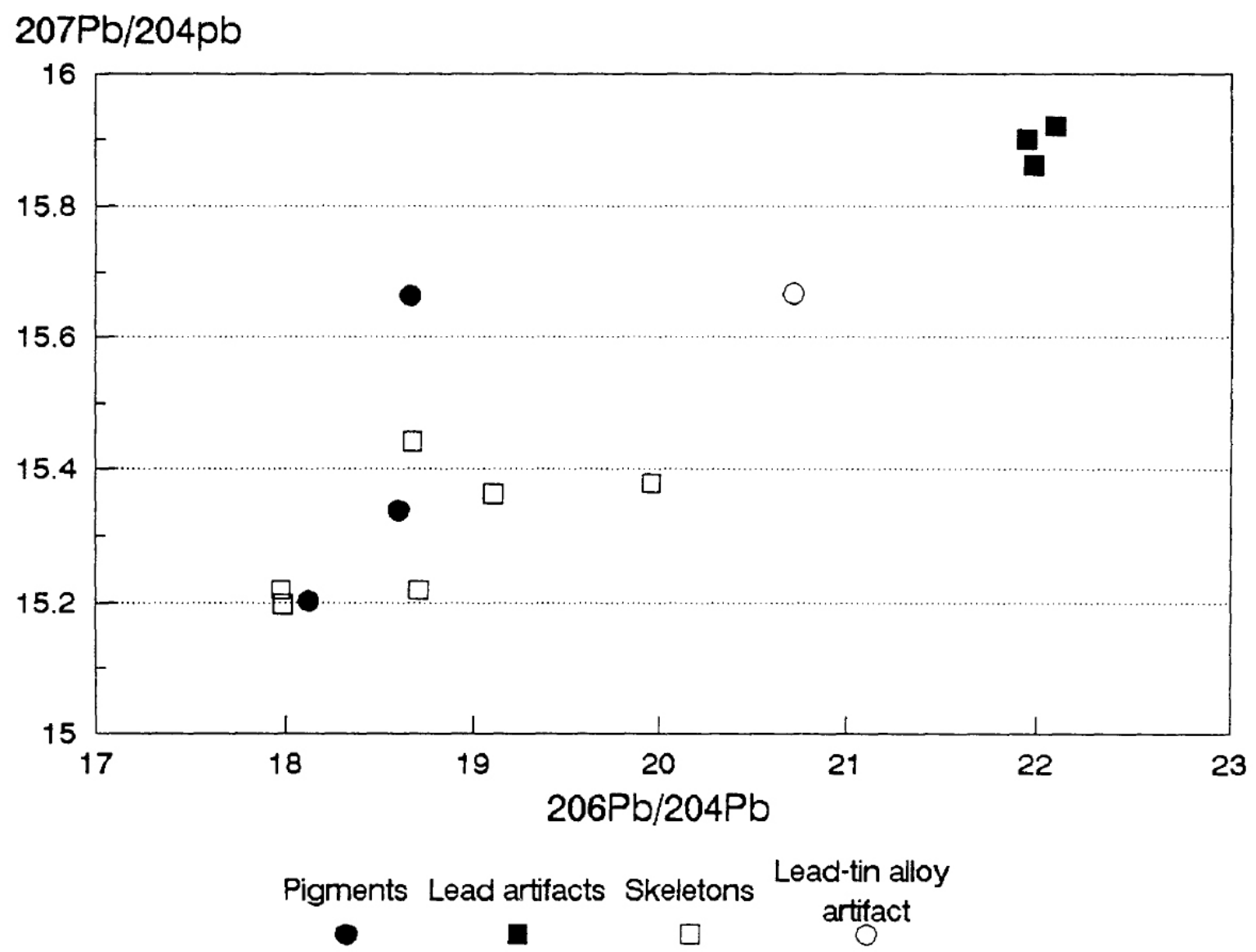

Fig. 2. Lead isotope analysis showing the distribution of metallic lead from musket balls, ornaments, and pigment samples. Note that the value for specimen $25 \mathrm{DK} 10-23 \mathrm{~b}$ is intermediate between the lead sources.

TABLE 3. Lead concentration values for individuals buried without lead artifacts or pigment

\begin{tabular}{lr}
\hline Burial No. & $\mathrm{Pb}(\mu \mathrm{g} / \mathrm{g})$ \\
\hline Children & \\
25DK2a s18 & 29.5 \\
25DK2a i2 & 71.2 \\
25DK10 i41 & 9.7 \\
25DK10 i29 & 68.4 \\
25DK10 i35 & 9.1 \\
25DK10 i29a & 13.2 \\
25DK10 i23a & 228.3 \\
25DK10 i23b & 331.1 \\
Adults & \\
25DK2a s17, sample 1 & 36.4 \\
25DK2a s17, sample 2 & 48.8 \\
25DK2a s19 & 7.1 \\
25DK10 i38 & 14.3 \\
25DK10 i37 & 13.7 \\
\hline
\end{tabular}

one has a mixed signal between metallic lead and lead pigment. This indicates that premortem absorption of at least metallic lead occurred. Therefore, premortem lead uptake and postmor- tem lead uptakeoccurred among the Omaha of the $18^{\text {th }}$ century.

Since mercury was a major component of the cosmetic pigment, we must address the possibility that mercury was absorbed in life. Only four individuals (25DK2b s29; 25DK10 i29a, i27b, and i55) revealed a mercury signal. The relative absence of mercury in comparison to lead can be explained by the relative affinity of these metals for bone apatite. Although hydroxyapatite crystals have a high affinity for lead ions, mercury ions have physicochemical features that prevent their firm bonding and incorporation in the crystal. The implications of these results are significant with respect to Omaha health in the late 1700s and early 1800s. It is clear that vermillion and a lead compound were mixed together as a cosmetic by the Omaha people. Although this pig- 
TABLE 4. Lead isotope ratio values for lead artifacts from $25 D K 10^{1}$

\begin{tabular}{|c|c|c|c|c|}
\hline $\begin{array}{l}\text { Artifact } \\
\text { solution }\end{array}$ & $\underset{(\mu \mathrm{g} / \mathrm{g})}{\text { Concentration }}$ & ${ }^{206} \mathrm{~Pb} /{ }^{204} \mathrm{~Pb}$ & ${ }^{207} \mathrm{~Pb} /{ }^{204} \mathrm{~Pb}$ & ${ }^{208} \mathrm{~Pb} /{ }^{204} \mathrm{~Pb}$ \\
\hline Coil 1 & 1.0 & 21.981 & 15.861 & 41.388 \\
\hline SD & & 0.114 & 0.076 & 0.215 \\
\hline RSD\% & & 0.520 & 0.491 & 0.525 \\
\hline Coil 2 & 1.0 & 21.943 & 15.900 & 41.294 \\
\hline SD & & 0.136 & 0.097 & 0.208 \\
\hline $\mathrm{RSD} \%$ & & 0.658 & 0.628 & 0.541 \\
\hline Musket ball & 1.0 & 22.091 & 15.920 & 41.580 \\
\hline SD & & 0.106 & 0.064 & 0.231 \\
\hline RSD\% & & 0.423 & 0.414 & 0.564 \\
\hline Buckle & 1.0 & 20.718 & 15.666 & 38.853 \\
\hline $\mathrm{SD}$ & & 0.136 & 0.097 & 0.208 \\
\hline RSD\% & & 0.658 & 0.628 & 0.541 \\
\hline Pigment 1 & & 18.603 & 15.339 & 38.264 \\
\hline SD & & 0.113 & 0.101 & 0.190 \\
\hline RSD\% & & 0.101 & 0.090 & 0.170 \\
\hline Pigment 2 & & 18.666 & 15.663 & 38.748 \\
\hline SD & & 0.084 & 0.101 & 0.318 \\
\hline RSD\% & & 0.075 & 0.090 & 0.285 \\
\hline Pigment 3 & & 18.122 & 15.202 & 38.875 \\
\hline SD & & 0.151 & 0.150 & 0.626 \\
\hline $\mathrm{RSD} \%$ & & 0.151 & 0.150 & 0.626 \\
\hline
\end{tabular}

${ }^{1}$ Each value is the mean of a 130 second scan.

TABLE 5. Lead concentrations and isotope ratios for $100 \mu \mathrm{g} / \mathrm{g}$ ashed powdered rib sample solutions ${ }^{1}$

\begin{tabular}{|c|c|c|c|c|}
\hline Skeleton & $\mathrm{Pb}$ Concentration & ${ }^{206} \mathrm{~Pb} /{ }^{204} \mathrm{~Pb}$ & ${ }^{207} \mathrm{~Pb} /{ }^{204} \mathrm{~Pb}$ & ${ }^{208} \mathrm{~Pb} /{ }^{204} \mathrm{~Pb}$ \\
\hline $25 \mathrm{DK} 10 \mathrm{i} 23 \mathrm{~b}$ & 331.1 & 19.958 & 15.379 & 38.638 \\
\hline SD & & 0.325 & 0.227 & 0.585 \\
\hline RSD\% & & 1.630 & 1.514 & 1.524 \\
\hline $25 \mathrm{DK} 10 \mathrm{i} 27 \mathrm{~b}$ & $2,567.0$ & 18.678 & 15.442 & 37.499 \\
\hline $\mathrm{SD}$ & & 0.697 & 0.468 & 1.220 \\
\hline RSD $\%$ & & 4.512 & 3.759 & 3.997 \\
\hline $25 \mathrm{DK} 10 \mathrm{i} 10$ & 862.5 & 19.109 & 15.364 & 37.699 \\
\hline $\mathrm{SD}$ & & 0.210 & 0.186 & 0.408 \\
\hline RSD\% & & 1.098 & 1.224 & 1.078 \\
\hline $25 \mathrm{DK} 10 \mathrm{i} 51$ & 877.6 & 17.987 & 15.198 & 36.689 \\
\hline SD & & 0.155 & 0.146 & 0.323 \\
\hline RSD\% & & 0.859 & 0.972 & 0.879 \\
\hline $25 \mathrm{DK} 10 \mathrm{il}$ & 479.2 & 18.711 & 15.219 & 36.902 \\
\hline SD & & 0.034 & 0.259 & 0.671 \\
\hline RSD\% & & 1.827 & 1.679 & 1.818 \\
\hline $25 \mathrm{DK} 2 \mathrm{~s} 2$ & 490.0 & 17.976 & 15.219 & 36.765 \\
\hline SD & & 0.162 & 0.182 & 0.345 \\
\hline $\mathrm{RSD} \%$ & & 0.897 & 1.201 & 0.9322 \\
\hline
\end{tabular}

${ }^{1}$ Each value is the mean of seven 130 second scans.

ment, when applied to a corpse, could easily be a source of culturally introduced diagenetic lead, it is also probable that the application of potent combination of lead and mercury to the face in life would have resulted in considerable metabolic uptake. This would have occurred, especially in children, with potential toxic effects for reasons explained by Reinhard and Ghazi (1992). The habit of painting the faces of children in the 1830s was documented by Prince Maximilian. He states
Mr. Bodmer made a sketch of the boy of an Omaha whom the father first daubed with red paint. He took vermillion in the palm of the hand, spat upon it, and then rubbed it in the boy's face. (Thomas and Ronnefeldt, 1982, p. 25).

Thus, the hands of the father and oral area of the child were contaminated with lead paint. This could easily cause ingestion of pigment. Maximilian also documents the use of the pig- 
TABLE 6. Student t-test evaluation of lead isotopic similarity between lead artifacts, pigment samples, and skeletons ${ }^{1}$

\begin{tabular}{lcccc}
\hline & d.f. & ${ }^{206} \mathrm{~Pb} /{ }^{204} \mathrm{~Pb}$ & ${ }^{207} \mathrm{~Pb} /{ }^{204} \mathrm{~Pb}$ & ${ }^{208} \mathrm{~Pb} /{ }^{204} \mathrm{~Pb}$ \\
\hline Artifacts vs. pigments & 5 & $\mathrm{~T}=2.558$ & $\mathrm{~T}=1.448$ & $\mathrm{~T}=0.774$ \\
& & $\mathrm{C}=.95-.98$ & $\mathrm{C}=.6-.8$ & $\mathrm{C}=.5-.6$ \\
Artifacts vs. skeletons & 8 & $\mathrm{~T}=1.715$ & $\mathrm{~T}=1.811$ & $\mathrm{~T}=1.098$ \\
& & $\mathrm{C}=.8-9$ & $\mathrm{C}=.8-.9$ & $\mathrm{C}=.6-.8$ \\
Pigments vs. skeletons & 7 & $\mathrm{~T}=0.362$ & $\mathrm{~T}=0.320$ & $\mathrm{~T}=1.492$ \\
& & $\mathrm{C}=.1-.5$ & $\mathrm{C}=.5-.5$ & $\mathrm{C}=.8-.9$ \\
\hline
\end{tabular}

1 "T" signifies T values and "C" signifies confidence intervals. $\mathrm{C}$ values of 0.8 or more represent significant differences.

ment among many Missouri River tribes that he visited during his 1833-34 journey. This indicates that the trade in mercury and lead based paints extended along the Missouri River from Nebraska to Montana. The use of lead and mercury cosmetics by the tribes in the region implies that lead contamination could have been experienced by more tribes in the Upper Missouri, and was not a phenomenon restricted to the Omaha Tribe.

\section{FURTHER CONSIDERATIONS}

Sandford (1993) suggests three strategies for recognizing diagenesis. She cites as most important the study of soil chemistry. Reinhard and Ghazi (1992) attempted this approach but with recently excavated burialsfrom 25KD2. However, the chemistry of the soils from 25DK10 has not been, and cannot be studied, due to the fact that the excavation was done in 1940. Secondly, Sandford also suggests specialized study of bone using X-ray diffraction, microprobe, and other techniques. This approach was not pursued in the Omaha analysis. It may be possible to apply these techniques to other Native American bones in Nebraska if the related tribes approve. Thirdly, Sandford (1993) suggests the comparative analysis of human bone with other species. This has been accomplished by Reinhard and Ghazi (1992) for the Omaha.

Beyond Sandford's suggestions, there are several additional issues of potential importance that could not be assessed in this study. Regarding lead isotope studies, it is unknown whether there is significant fractionation of the isotopes during premortem or postmortem absorption. We assume that the heavy weight of lead minimizes fractionation between isotopes, but this has not been verified.

The analysis of soil that Sandford suggests is complicated by the potential release of ions from two different sources of culturally introduced diagenetic lead in the Omaha burials. We have a poor idea of how lead ions from the different sources of lead (pigment and artifacts) act in the burial soils. There is the potential of differential release of ions between the lead pigment and the lead artifacts. We do not know how lead ions react in the soil matrix chemistry; for example, we do not know how far lead ions move in the burial soils. We cannot assess how much lead is mobile in water, how much is tied into the crystal structure of soil constituents, or how much remains exchangeable on the surface of clays. An understanding of these issues would be beneficial in assessing the relative contribution of diagenetic lead to the trace elemental signals. Unfortunately, these issues could not be evaluated because we were not involved in the W.P.A. excavation of the burials and therefore could not test the soils. This sort of analysis has proven useful in more modern trace element studies (Edward and Benfer, 1993).

Finally, the influence of mercury could not be assessed with the extraction procedures used in this study. It may be insightful to test the nonapatite component of bone to assess the presence or absence of mercury.

Evidence of widespread trade of red pigmentis available from other skeletons in Nebraska. Recently, remains of three Pawnee dating to the late 1700 s or early 1800 s were excavated. All exhibited red pigment application to the bones or burial bundles. Similarly, Ponca skeletons dating to the late 18th century are often painted. If permitted by the Ponca tribes of Oklahoma and Nebraska, continued study will focus on Ponca skeletons to verify lead contamination of other Nebraska tribes. As additional excavations are 
done on a salvage basis, we hope that we can incorporate Sandford's suggestions to more rigorously assess lead contamination in historic Native Americans in Nebraska.

\section{ACKNOWLEDGMENTS}

This and previous analyses were sponsored by the Omaha Tribe of Nebraska who recognize the value of such study in gaining insight into their ancestral past. The analysis was funded by the office of the Vice Chancellor for Research, University of Nebraska-Lincoln.

\section{LITERATURE CITED}

Edward JB and Benfer RA (1993) The effects of diagenesis on the Paloma skeletal material. In MK Sandford (ed.): Investigations of Ancient Human Tissue: Chemical Analyses in Anthropology. Langhorne, PA: Gordon and Breach Science Publishers, pp. 183-268.
Ghazi AM, Durrance EM, Sandness KL and Reinhard KJ (1992) ICPIMS determination of $\mathrm{Pb}$ and $\mathrm{Pb}$ isotope ratios in bones and artifacts of a Native American tribe: $\mathrm{a} \mathrm{Pb}$ poisoning and $\mathrm{Pb}$ source study. Washington, D.C.: Proceedings of the 40th ASMS conference on Mass Spectrometry and Allied Topics.

Morrison SE (1920) Letters on the Northwest fur trade. Washington Hist. Q. 11: 174-177.

Reinhard KJ and Ghazi AM (1992) Evaluation of lead concentrations in Nebraska Skeletons Using ICPMS. Am. J. Phys. Anthropol. 89: 183-195.

Sandford MK (1993) Understanding the biogenic-diagenetic continuum: interpreting elemental concentrations of archaeological bone. In MK Sandford (ed.): Investigations of Ancient Human Tissue: Chemical Analyses in Anthropology. Langhorne, PA: Gordon and Breach Science Publishers, pp. 3-57.

Thomas D and Ronnefeldt K (1982) People of the First Man. New York: Promontory Press. 